\title{
Relationships between macroseismic intensity and peak ground acceleration and velocity for the Vrancea (Romania) subcrustal earthquakes
}

\author{
Angela Petruta Constantin*, Iren-Adelina Moldovan, Raluca Partheniu, \\ Bogdan Grecu, Constantin Ionescu
}

National Institute for Earth Physics, Calugareni 12, 077125, Magurele, Romania

Article history: received March 23, 2020; accepted April 28, 2021

\begin{abstract}
The goal of this paper is to develop a new empirical relationship between observed macroseismic intensity and strong ground motion parameters such as peak ground acceleration (PGA) and velocity (PGV) for the Vrancea subcrustal earthquakes. The recent subcrustal earthquakes provide valuable data to examine these relationships for Vrancea seismogenic region. This region is one of the most active seismic zones in Europe and it is well-known for the strong subcrustal earthquakes. We examine the correlation between the strong ground-motion records and the observed intensities for major and moderate earthquakes with $\mathrm{Mw} \geq 5.4$ and epicentral intensity in the range VI to IX MSK degrees that occurred in Vrancea zone in the period 1977-2009. The empirical relationships between maximum intensity and ground parameters obtained and published by various authors have shown that these parameters do not always show a one-to-one correspondence, and the errors associated with the intensity estimation from PGA/PGV are sometimes +/-2 MSK degree. In the present study, the relation between macroseismic intensity and PGA/PGV will be given both as a mathematical equation, but also as corresponding ground motion intervals. Because of the intensity data spreading and errors related to mathematical approximations, it is necessary to systematically monitor not only the acceleration and velocity but also all the other ground motion parameters. The mathematical relation between these parameters might be used for the rapid assessment of ground shaking severity and potential damages in the areas affected by the Vrancea earthquakes.
\end{abstract}

Keywords: Vrancea seismogenic region; Intermediate-depth earthquake; Macroseismic intensity; Peak ground acceleration; Peak ground velocity.

\section{Introduction}

The past bad experience from the last decades caused by worldwide natural disasters, especially those associated with major earthquakes which has determined defensive measures from the international communities. A review of human and material losses caused by natural disasters shows that most of them are consequences of earthquakes. However, in high seismic risk areas, prevention and protection measures of the population and infrastructure must be applied, including the anti-seismic design of civil, industrial, nuclear, military buildings, etc. Some of the 


\section{Angela Petruta Constantin et al.}

parameters needed in such studies are macroseismic intensity (MI) and ground motion parameters, these parameters describing the degree of ground shaking for earthquakes. The peak ground motion parameters (PGM) that are measured using strong-motion networks provide a more objective representation of the degree of seismic motion [Kramer, 1996; Linkimer, 2008]. Nevertheless, in the absence of strong ground motion instrumental recordings, the macroseismic intensity, as a descriptive measure, can give us useful information about the regional distribution of earthquakes' effects and their dependence on hypocentral distance, geo-tectonics, regional and local structural conditions. Due to the fact that instrumental seismology only appeared at the end of the XIX ${ }^{\text {th }}$ Century, was necessary to use in earthquake engineering the macroseismic intensity. Moreover, the macroseismic information are extended on many centuries, and in Romania, the first sustained macroseismic investigation was accomplished in 1892 [Hepites, 1902]. Many macroseismic data regarding the effects of past major Romanian earthquakes were structured by Atanasiu [1961]. Presently the macroseismic database contains large information of the Romanian earthquakes covering a time period ranging from 1000 to the year 2019 [i.e., Constantin et al., 2011, 2013, 2016, 2018; Pantea and Constantin, 2011, 2013].

A major advantage of using the macroseismic intensities is represented by the long-time coverage, both for the historical period, characterized by the absence of direct measurements of the strong ground motion, but also during the instrumental period.

Due to the insufficient number of strong-motion stations, we must appeal to the approximation of the measurable values, through deductible values based on some models. The simplest models (appropriate for the actual state of recording instruments) are those that establish (i) the empirical predictive relations [Grecu et al., 1981; Pantea, 1999; Pantea and Crisan, 1993; Moldovan et al., 2000; Marmureanu et al., 2006; Popescu et al., 2007; Ardeleanu et al., 2012] or (ii) empirical correlation relations between the macroseismic intensity and strong motion parameters (like PGA, PGV, PGD, etc.) [Pantea, 1992; Enescu, 1997; Bonjer, 2001; Sørensen et al., 2008]. Mainly, these relations adopt the hypothesis of a monotonous decrease of motion parameters with distance and based on recorded data of some earthquakes empirical functions holding mainly between distance, source parameters and site factor were deduced through the minimization method of standard deviation (least squares method). These relations allow the interpolation and even extrapolation of the maximum acceleration and velocity values from points where the measured values are known to interest points where we do not have records.

The data characterizing the seismic ground motion is of fundamental importance for the seismic hazard assessment, which emphasizes the particularities of the active Vrancea seismogenic zone [Apostol et al., 2020; Marmureanu et al., 2020]. The maximum horizontal acceleration and velocity describe with a good approximation the ground motion and can be used in earthquake engineering applications, having a high potential to incorporate all the soil movement characteristics - both in time and in frequency, although PGV is less sensitive to the highest frequency content and more sensitive to the intermediate frequency range [Kramer, 1996; Zanini et al., 2019].

Along time many studies have investigated and developed statistical relationships between macroseismic intensity and ground motion parameters for various seismic regions of the world [Trifunac and Brady, 1975; Murphy and O’Brien, 1977; Chernov and Sokolov, 1988; Sweny, 2012; Ren et al., 2013; Bilal, 2013; Nemati, 2015; Caprio et al., 2015; Ogweno and Cramer, 2017; Zanini et al., 2019, etc.]. Some of the previous studies have suggested that empirical relationships between these parameters are specific for each seismic region and therefore they should be carefully applied for particular regions [Murphy and O'Brien, 1977; Kaka and Atkinson, 2004; Linkimer, 2008], and we complete the statement that the conversion relations are specific not only for the seismogenic source but also for each individual recording site. One of the first attempts to correlate these parameters was made in MSK-64 intensity scale [Medvedev et al., 1967] (which is still in use in Romania), proposing a range of PGA and PGV for each degree of intensity (see Table 1).

In Romania, first attempts regarding the analytical relations MI-PGM for the Vrancea subcrustal earthquakes were made in the past by various authors [i.e., Sandi, 1986, 1990; Pantea, 1992; Radu, 1991]. The occurrence of the earthquakes from 1986 and 1990 offered the opportunity to quantify the seismic motion severity due to numerous valuable instrumental data recorded after these events [Radu et al., 1990]. In the last period this subject of correlation between macroseismic intensity and ground motion parameters it was of interest for other studies developed for more or less the same data set [i.e., Enescu, 1997; Bonjer et al., 2001; Sørensen et al., 2008]. Regarding the macroseismic information, unfortunately, these are decreasing in time because the population is not willing to spend time and fill in questionnaires [Constantin et al., 2018]. All the macroseismic data used in this study are from questionnaires (like DYFI) conventionally collected from territory soon after the earthquakes occurrence. 
Correlation of intensity with ground motion parameters

\begin{tabular}{ccccc} 
Intensity & PGA $\left(\mathbf{c m} / \mathbf{s}^{2}\right)$ & PGV $(\mathbf{c m} / \mathbf{s})$ & $\begin{array}{c}\text { Perceived } \\
\text { shaking }\end{array}$ & $\begin{array}{c}\text { Potential } \\
\text { damage }\end{array}$ \\
V & $12 \div 25$ & $1 \div 2$ & Moderate & Very light \\
\hline VI & $26 \div 50$ & $2,1 \div 4$ & Strong & Light \\
\hline VII & $51 \div 100$ & $4,1 \div 8$ & Very strong & Moderate \\
\hline VIII & $101 \div 200$ & $8,1 \div 16$ & Severe & Heavy \\
\hline IX & $201 \div 400$ & $16,1 \div 32$ & Violent & Very heavy \\
\hline
\end{tabular}

Where PGA - peak ground acceleration for periods of $0.1 \div 0.5 \mathrm{~s}$; PGV - peak ground velocity for periods of $0.5 \div 5 \mathrm{~s}$

Table 1. Macroseismic intensity versus peak ground acceleration in the MSK scale (STAS 3684-71 used for intensity).

Empirical relationships between macroseismic intensity and ground motion parameters are one of the evident applications used to obtain intensities directly from recorded data or to estimate PGA and PGV data for historical earthquakes and not only, in sites where macroseismic information are available. Another major use of such relationships is represented by the Shake map application (the program automatically generates maps of ground shaking and provides a rapid assessment of intensities and possible damage, after an earthquake [Wald et al., 1999a, 1999c, 2006]. This type of map is useful for disaster mitigation, management and authority rapid response purposes, and also for civil society.

The main purpose of our study is to develop new relations that can be used to estimate very quick macroseismic intensities of the recent intermediate-depth earthquakes, which accelerations and velocities are known, as well as inferring approximated values of seismic intensities during future earthquakes. Figure 1 shows the spatial distribution of the selected seismic events and the location of the stations. The evaluated and reevaluated macroseismic intensities and strong ground motion database recorded during the major and moderate (Mw $\geq 5.4)$ Vrancea intermediate-depth earthquakes of March 4, $1977\left(\mathrm{M}_{\mathrm{W}}=7.4\right)$, August 30, $1986\left(\mathrm{M}_{\mathrm{W}}=7.1\right)$, May 30, $1990\left(\mathrm{M}_{\mathrm{W}}\right.$ = 6.9), May 31, $1990\left(\mathrm{M}_{\mathrm{W}}=6.4\right)$, October 27, $2004\left(\mathrm{M}_{\mathrm{W}}=6.0\right)$ and April 25, $2009(\mathrm{Mw}=5.4)$ have been used to obtain these relations (see Table 2).

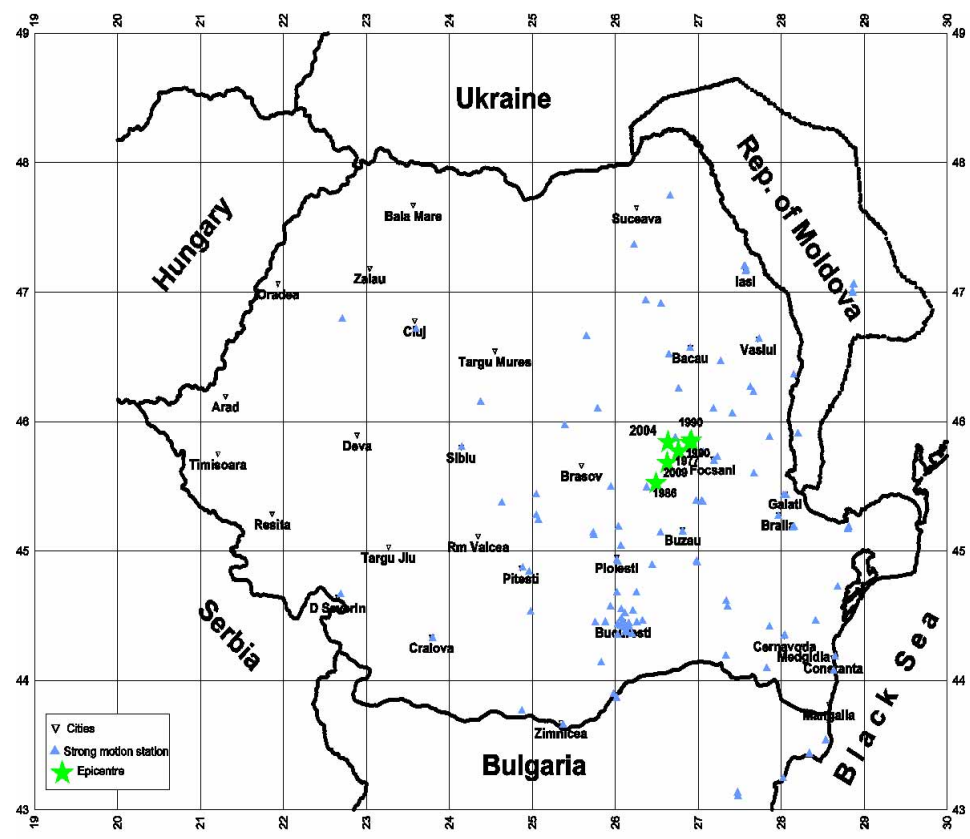

Figure 1. The epicenters of the studied seismic events (green stars) and the strong ground motion network that recorded these earthquakes (blue triangles). 


\section{Angela Petruta Constantin et al.}

\begin{tabular}{ccccccccc} 
No. & Date & Time & Lat. $\mathbf{N}$ & Long. $\mathbf{E}$ & Depth $(\mathbf{k m})$ & $\mathbf{M}_{\mathbf{W}}$ & \multicolumn{2}{c}{ Io (Romplus) } \\
\hline 1 & 04.03 .1977 & $19: 21: 54$ & 45.77 & 26.76 & 94 & 7.4 & IX \\
\hline 2 & 30.08 .1986 & $21: 28: 37$ & 45.52 & 26.49 & 131 & 7.1 & VIII-IX \\
\hline 3 & 30.05 .1990 & $10: 40: 06$ & 45.83 & 26.89 & 91 & 6.9 & VIII \\
\hline 4 & 31.05 .1990 & $00: 17: 48$ & 45.85 & 26.91 & 87 & 6.4 & VII \\
\hline 5 & 27.10 .2004 & $20: 34: 36$ & 45.84 & 26.63 & 105 & 6.0 & VI \\
\hline 6 & 25.04 .2009 & $05: 18: 48$ & 45.68 & 26.62 & 109 & 5.4 & VI \\
\hline
\end{tabular}

Table 2. Parameters of the earthquakes used in this study.

Using the PGM data and the macroseismic intensities available around the recording stations we obtained the following empirical relations: $M I=0.169+3.51 * \log P G A$, and $M I=4.16+3.04 * \log P G V$. For the earthquakes used in this study, the ground motion parameters (PGA and PGV) database contains more than 450 records, but less than the intensity data points (IDPs data set) obtained for the same events (4700 IDPs for all events).

\section{Seismicity of the Vrancea region}

Vrancea seismic zone is responsible for $90 \%$ of the seismic activity in Romania, thus releasing more than $95 \%$ of the total seismic energy. Therefore, the seismicity of the Romanian territory and its specific pattern is strongly determined by the Vrancea seismogenic zone because all the major damaging earthquakes from Romania have originated within this zone. The Vrancea seismogenic zone is located at the Southeastern Carpathians Arc bend, probably centered upon the triple junction of the three tectonic units (the East European plate, the Intra-Alpine subplate, and the Moesian subplate) [Airinei, 1977], and is one of the most active seismic areas in Europe. This region is characterized by strong subcrustal earthquakes $\left(\mathrm{M}_{\mathrm{W}}>7.0\right.$ ), with a low frequency of occurrence (3-4 destructive earthquakes per century). The crustal seismicity of this region is characterized by moderate earthquakes with magnitudes that have not exceeded $\mathrm{M}_{\mathrm{W}}=5.9$ [Oncescu et al. 2000, Romplus catalogue, 2019].

In the last century, two destructive subcrustal earthquakes struck the territory of Romania: on October 11, 1940, and on March 4, 1977. Both events caused severe damage in the Romanian territory and killed or injured thousands of people [Pantea and Constantin, 2011, 2013]. The March 1977 earthquake represents the greatest tragedy in the past 40 years in Romania that resulted in major human and property losses, especially in urban centers with high population density and constructions, such as Bucharest, Craiova, Zimnicea, Turnu Magurele, etc. The earthquake caused 1,578 deaths (1,424 only in Bucharest), 11,300 injuries and about 35,000 buildings were severely damaged or collapsed. Zimnicea town was completely destroyed. A value of IX-X in the MSK scale was assigned to many locations after the revision of macroseismic effects. In the corresponding intensities map for this event, stand out a lot of marked locations/areas with maximum values, in the Southern part of Romania [Constantin et al., 2020]. The next major seismic events that occurred in the Vrancea seismogenic region are the earthquakes from August 30, 1986, and May 30 and 31, 1990. The August 30 seismic event was felt in a large area, and it caused serious damages in the epicentral area, including the collapse of a church. Two people were killed, 558 injured, and about 55,000 homes were partially damaged. No victims or severe damage were reported after the occurrence of the 30 and 31 May earthquakes. The last $\mathrm{Mw} \geq 6.0$ earthquake that occurred in this region was October 27, 2004, subcrustal earthquake, which was the only significant event over the last almost three decades, both in terms of magnitude and observed macroseismic effects [Constantin and Pantea, 2013]. This caused general panic and minor-tomoderate damage to the buildings in the epicentral area and Bucharest [Constantin et al., 2020].

\section{Database}

This chapter will provide summary statistics about the parameters of the studied earthquakes, including date, 
location, magnitude and depth (Table 2) and the related recorded ground motion parameters and intensity observations.

For this study were used the accelerations and velocities recorded in various points from Romania by the strong motion networks during strong and moderate earthquakes (see Table 2), and their associated macroseismic data [Radu et al., 1987, 1990, 1991; Constantin and Pantea, 2013, 2018; Pantea and Constantin, 2013] obtaining relations for PGA and PGV versus macroseismic intensity for $\mathrm{I} \geq \mathrm{V}$.

After the seismic event of March 4, 1977, with two accelerometer recordings obtained only in Bucharest, the Romanian seismic network developed rapidly, thus, in 1980 the Romanian accelerographic network had already increased to 78 instruments. The number of strong-motion stations continued to increase, thus approximately 160 recordings were obtained for the earthquakes from 1986 and 1990's in more than 40 points [Borcia, 2006]. These strong-motion stations were switched in 1997 to a new network using K2-digital accelerographic, and nowadays the national seismic network consists of 147 stations, equipped with velocity and/or acceleration sensors, a short period (SP) and/or broadband (BB). Table 3 presents min and max values of the maximum horizontal acceleration and velocity recorded by strong motion network during the studied earthquakes, extracted from the total number of records.

Summary statistics are given for the types of used data: the ground motion data (Table 3), the IDP database (Table 4) and the matched pairs of MSK macroseismic - ground motion data (Table 5). The number of IDP varies on the basis of the earthquake size, with a minimum of 475 for the M 6.0 October 2004 event to a maximum of 1620 for the M 7.4 March 1977 event (Table 4).

\begin{tabular}{|c|c|c|c|c|c|c|c|c|c|}
\hline No. & $\begin{array}{l}\text { Seismic } \\
\text { event }\end{array}$ & $\mathbf{M}_{\mathbf{W}}$ & $\begin{array}{l}\text { Total no. } \\
\text { of records }\end{array}$ & \multicolumn{2}{|c|}{ PGA $\left(\mathrm{cm} / \mathrm{s}^{2}\right)$} & \multicolumn{2}{|c|}{ PGV (cm/s) } & $\begin{array}{l}\text { Hypocentral } \\
\text { distance (km) }\end{array}$ & Locality \\
\hline 1 & 4.03 .1977 & 7.4 & 2 & \multicolumn{2}{|c|}{207.6} & \multicolumn{2}{|c|}{58.5} & 181 & Bucharest \\
\hline \multirow{2}{*}{2} & \multirow{2}{*}{30.08 .1986} & \multirow{2}{*}{7.1} & \multirow{2}{*}{75} & Max val & 297 & Max val & 32 & 143 & Focsani \\
\hline & & & & Min val & 8 & Min val & 1 & 312 & Deva \\
\hline \multirow{2}{*}{3} & \multirow{2}{*}{30.05 .1990} & \multirow{2}{*}{6.9} & \multirow{2}{*}{74} & Max val & 270 & Max val & 36 & 151 & Campina \\
\hline & & & & Min val & 24 & Min val & 4 & 204 & Arges \\
\hline \multirow{2}{*}{4} & \multirow{2}{*}{31.05 .1990} & \multirow{2}{*}{6.4} & \multirow{2}{*}{52} & Max val & 162 & Max val & 19 & 91 & Focsani \\
\hline & & & & Min val & 12 & Min val & 0.8 & 246 & Giurgiu \\
\hline \multirow{2}{*}{5} & \multirow{2}{*}{27.10 .2004} & \multirow{2}{*}{6.0} & \multirow{2}{*}{41} & Max val & 264 & Max val & 15 & 144 & Seciu \\
\hline & & & & Min val & 0.18 & Min val & 0.2 & 336 & Dragan \\
\hline \multirow{2}{*}{6} & \multirow{2}{*}{25.04 .2009} & \multirow{2}{*}{5.4} & \multirow{2}{*}{47} & Max val & 55 & Max val & 2.4 & 138 & Seciu \\
\hline & & & & Min val & 0.04 & Min val & 0.003 & 402 & Buzias \\
\hline
\end{tabular}

Table 3. Minimum and maximum values of PGA and PGV recorded by the accelerographic network from Romania for the earthquakes studied in this paper.

\begin{tabular}{ccccc} 
Seismic event & No. IDP & Imax(MSK) & Imin & Epicentral distances (km) \\
4.03 .1977 & 1620 & IX-X & II & $5 \div 478$ \\
\hline 30.08 .1986 & 950 & IX & II & $9 \div 458$ \\
\hline 30.05 .1990 & 705 & VIII-IX & II & $9 \div 452$ \\
\hline 31.05 .1990 & 510 & VIII & II & $7 \div 464$ \\
\hline 27.10 .2004 & 475 & VII & III & $6 \div 450$ \\
\hline 25.04 .2009 & 531 & VI & II & $29 \div 424$ \\
\hline
\end{tabular}

Table 4. Summary statistics for IDP of studied earthquakes. 


\section{Angela Petruta Constantin et al.}

\begin{tabular}{ccccccc}
$\begin{array}{c}\text { Seismic } \\
\text { event }\end{array}$ & $\begin{array}{c}\text { No of MI-PGA } \\
\text { pairs }\end{array}$ & $\begin{array}{c}\text { No of MI-PGV } \\
\text { pairs }\end{array}$ & $\begin{array}{c}\text { Intensity } \\
\text { range }\end{array}$ & $\begin{array}{c}\text { PGA range } \\
\left(\mathbf{c m} / \mathbf{s}^{2}\right)\end{array}$ & $\begin{array}{c}\text { PGV range } \\
(\mathbf{c m} / \mathbf{s})\end{array}$ & $\begin{array}{c}\text { Distance range } \\
(\mathbf{k m})\end{array}$ \\
\hline 4.03 .1977 & 1 & 1 & VIII-IX & 207.6 & 58.5 & 155 \\
\hline 30.08 .1986 & 47 & 43 & V $\div$ IX & $12.4 \div 297.1$ & $1.2 \div 32$ & $43 \div 250$ \\
\hline 30.05 .1990 & 64 & 64 & V $\div$ VIII & $24.6 \div 270.6$ & $3 \div 36$ & $14 \div 307$ \\
\hline 31.05 .1990 & 46 & 46 & V $\div$ VIII & $11.8 \div 162$ & $0.8 \div 19$ & $15 \div 232$ \\
\hline 27.10 .2004 & 34 & 34 & V $\div$ VII & $9.5 \div 264.35$ & $0.5 \div 15.3$ & $2 \div 279$ \\
\hline 25.04 .2009 & 26 & 26 & V $\div$ VI & $1.08 \div 55.4$ & $0.8 \div 2.4$ & $19 \div 246$ \\
\hline
\end{tabular}

Table 5. Description of matched MI-PGM, including the number of pairs, and the MI and distance range covered.

In this study we used records from stations located both in the free field and in the basement of buildings. A total of 218 values of PGM were associated with MI values from all 6 earthquakes. The ground motion parameters are defined as the largest of the horizontal components. The majority of the MI- PGM data is distributed in the intensity range of V-VII (94\%).

Maps with the PGA were also constructed, corresponding to all the studied earthquakes. In Figure 2 is presented the map with IDPs and the only one seismic waveform for the 1977 earthquake and in Figure 3 are presented simultaneously both maps (intensity and PGA) for all the last five earthquakes.

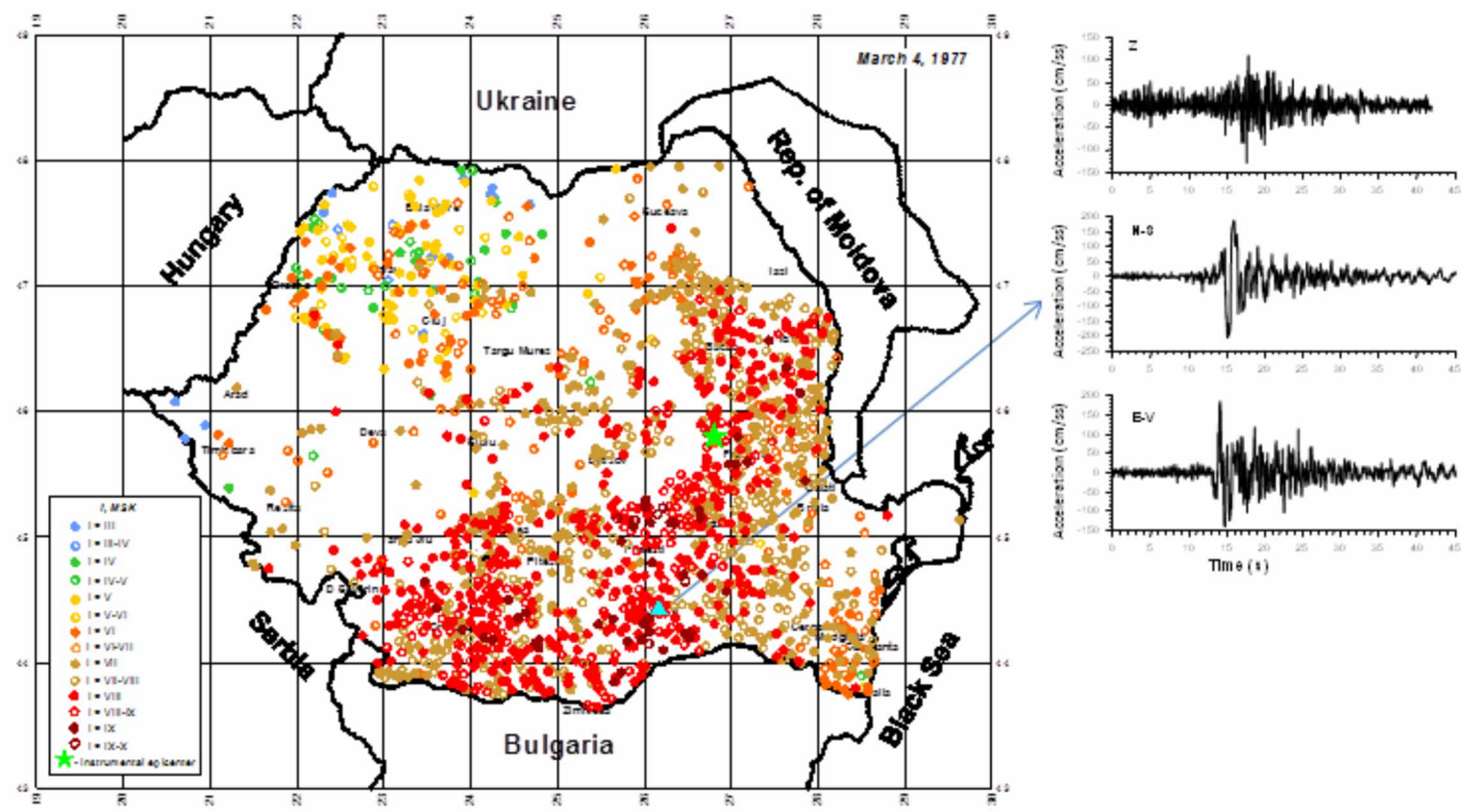

Figure 2. Reevaluated macroseismic intensity map and strong motion record (INCERC station in Bucharest) of March 4, 1977 earthquake.

For the period in which the studied earthquakes have occurred, the instrumental data are less abundant than intensity data. Nonetheless, some earthquakes are quite well-recorded, with ground motion records like PGA in a wide range of distances and values from 0.198 to $297.1 \mathrm{~cm} / \mathrm{s}^{2}$. As Sweny [2012] said, the well-documented earthquakes allow detailed analysis of ground motions, macroseismic intensity, and their interactions, as well as the role of contributing variables like region, distance, magnitude and site condition on these relations. The next section will explore only the correlation between macroseismic intensity and peak ground parameters for the set of earthquakes presented above, without contribution of other variables like magnitude, distance or local conditions. 

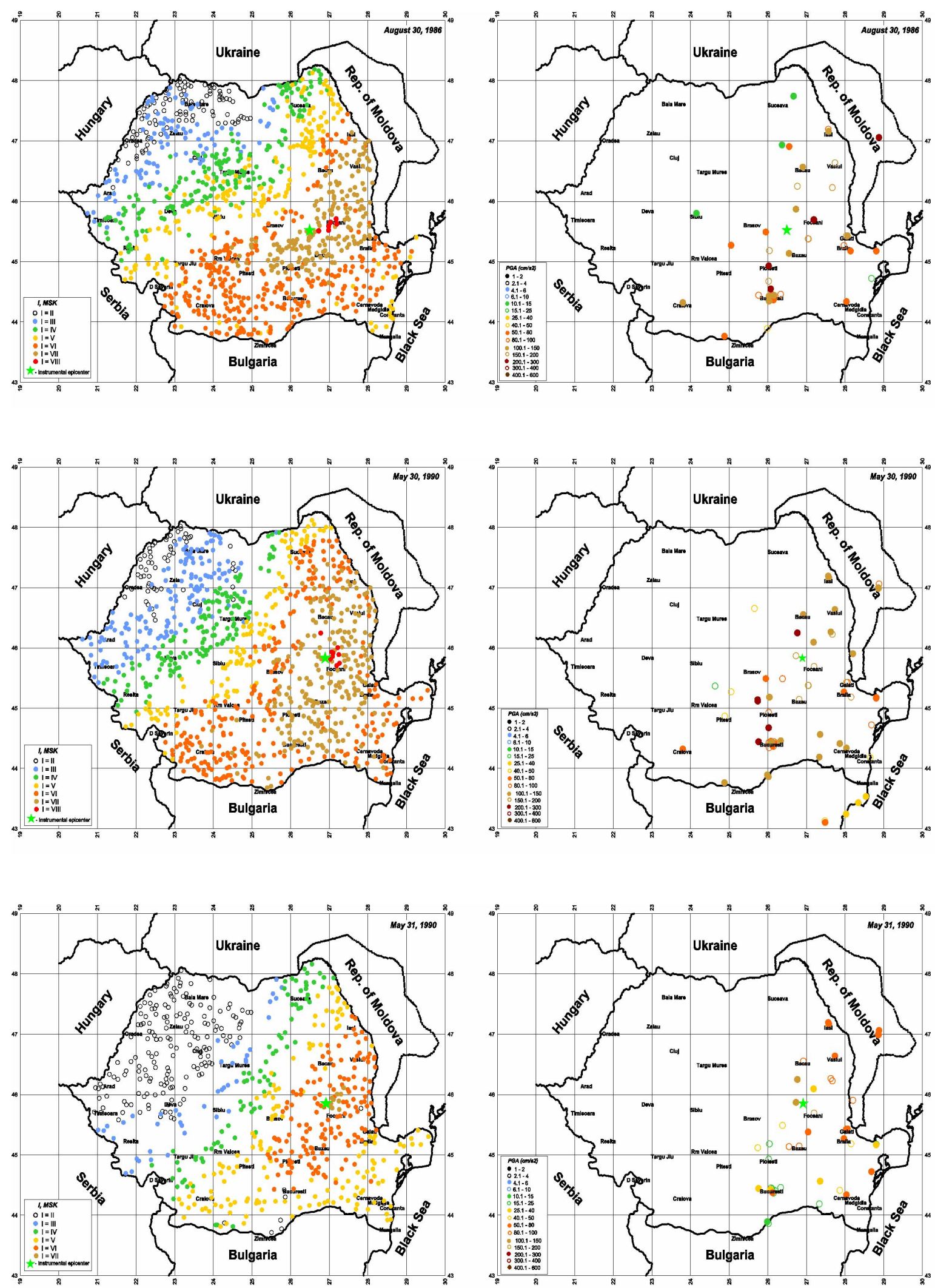

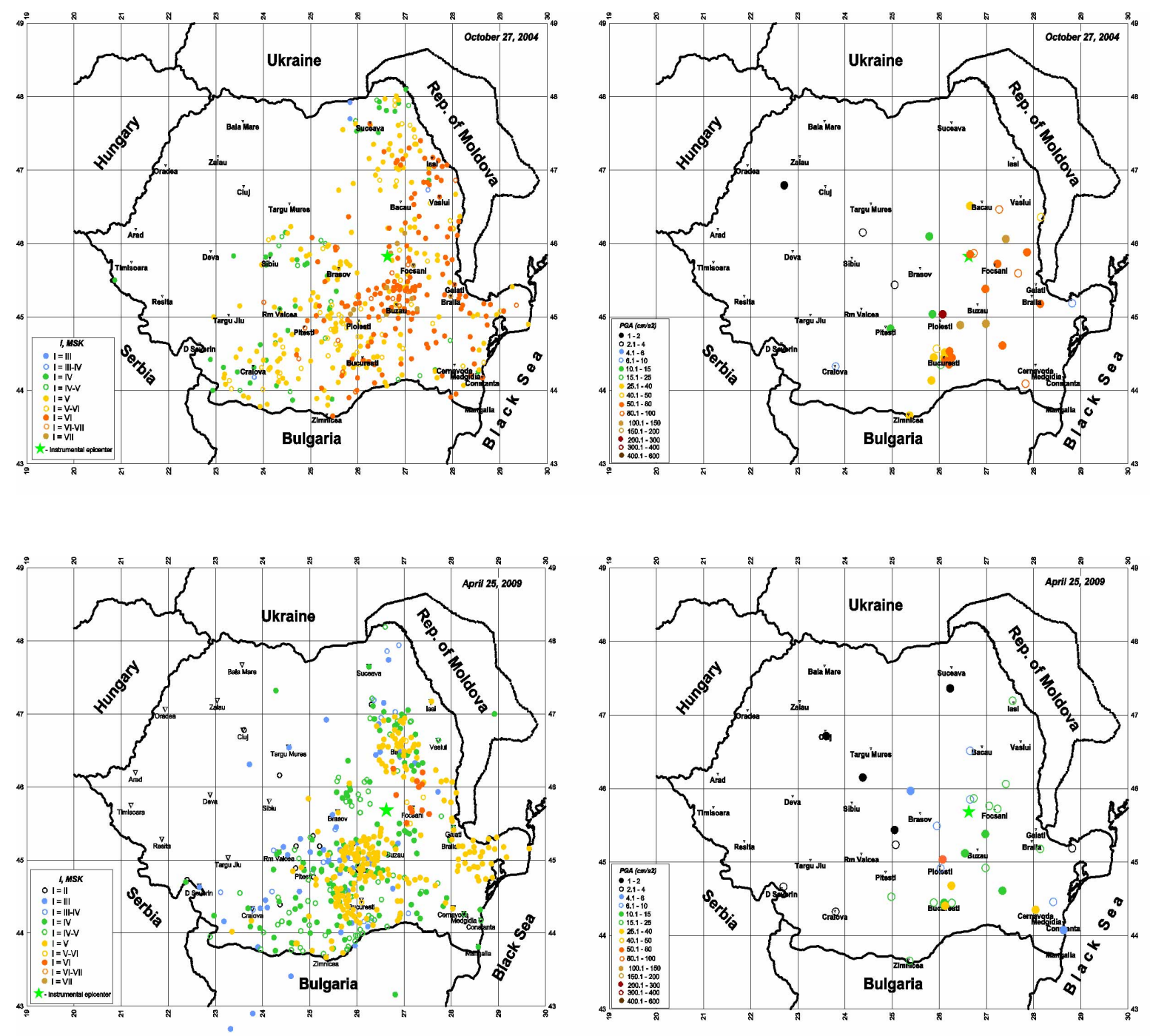

Figure 3. Macroseismic intensity and PGA maps for the studied earthquakes.

\section{Proposed relations between MI and PGM for intermediate-depth earthquakes}

The diversity of the types of geological structures certifies that the relations between the ground motion and local characteristics at each station are weakly understood and very complex. The relation between the type of structure and the ground motion parameters describing the strength was emphasized by many authors [Campbell, 1981,1983; Chiaruttini and Siro, 1981; Faccioli, 1981]. The characteristics of the geological structures have a different influence on the parameters of the ground movement (acceleration, velocity, displacement, etc.), depending on the hypocentral distance and on the size of the earthquake, due to different frequencies content.

The short distance variation of the maximum soil acceleration values recorded during an earthquake lead to a comparison of the studied parameters, concluding that: for the same seismic event recorded at equal distance, but on different sites (with different local conditions) both the dynamic parameters (acceleration, velocity, displacement, spectrum) and the macroseismic intensity were different. In this context, three types of local effects were distinguished, attributed to the slightly consolidated geological strata, topography and lateral discontinuities in the soil structure. The first type is most common and could be considered as an explanation for high macroseismic effects generated by the earthquakes in some places, indicating that the local conditions can sometimes amplify the destructive effects up to 2-3 intensity degrees [Pantea and Constantin, 2013]. Also, Mandrescu [1995] noticed that 
the regional and local geological conditions have an important role in the distribution of macroseismic effects of the Vrancea subcrustal earthquakes, being also observed in the case of the 1986, and 1990 earthquakes. The amplification effect is explained by the difference in mechanical impedance between the geological strata weakly consolidated (soft) and the base one (hard), being influenced by the local tectonics and the geometry of the weak strata [Campbell, 1983; Chiaruttini and Siro, 1981; Faciolli, 1981].

When PGM is related to the macroseismic intensity a useful criterion is to correlate only those values recorded at the stations located at no more than 3 kilometers from the observed intensity [Wald et al., 1999b]. Therefore, we selected the corresponding intensity value for each strong-motion station, by taking the nearest MI value to the station. In order to observe the distribution of the data used we plotted MI and log PGM vs. distance from the epicenter to the station, and MI vs. $\log$ PGM (Figure 4). The intensities are between V and IX MSK degrees and for ground motion parameters the maximum values are $297.1 \mathrm{~cm} / \mathrm{sec}^{2}$ for PGA and $58.5 \mathrm{~cm} / \mathrm{sec}$ for PGV, respectively. The average distance for all MI-PGM pairs is $140 \mathrm{~km}$, with a maximum distance of $328 \mathrm{~km}$.

A lot of studies existing on this subject use the linear least squares regression and some orthogonal distance regression (ODR). To calculate MI and to obtain the ranges of PGA and PGV we have used only ODR, because it's more appropriate to our needs.
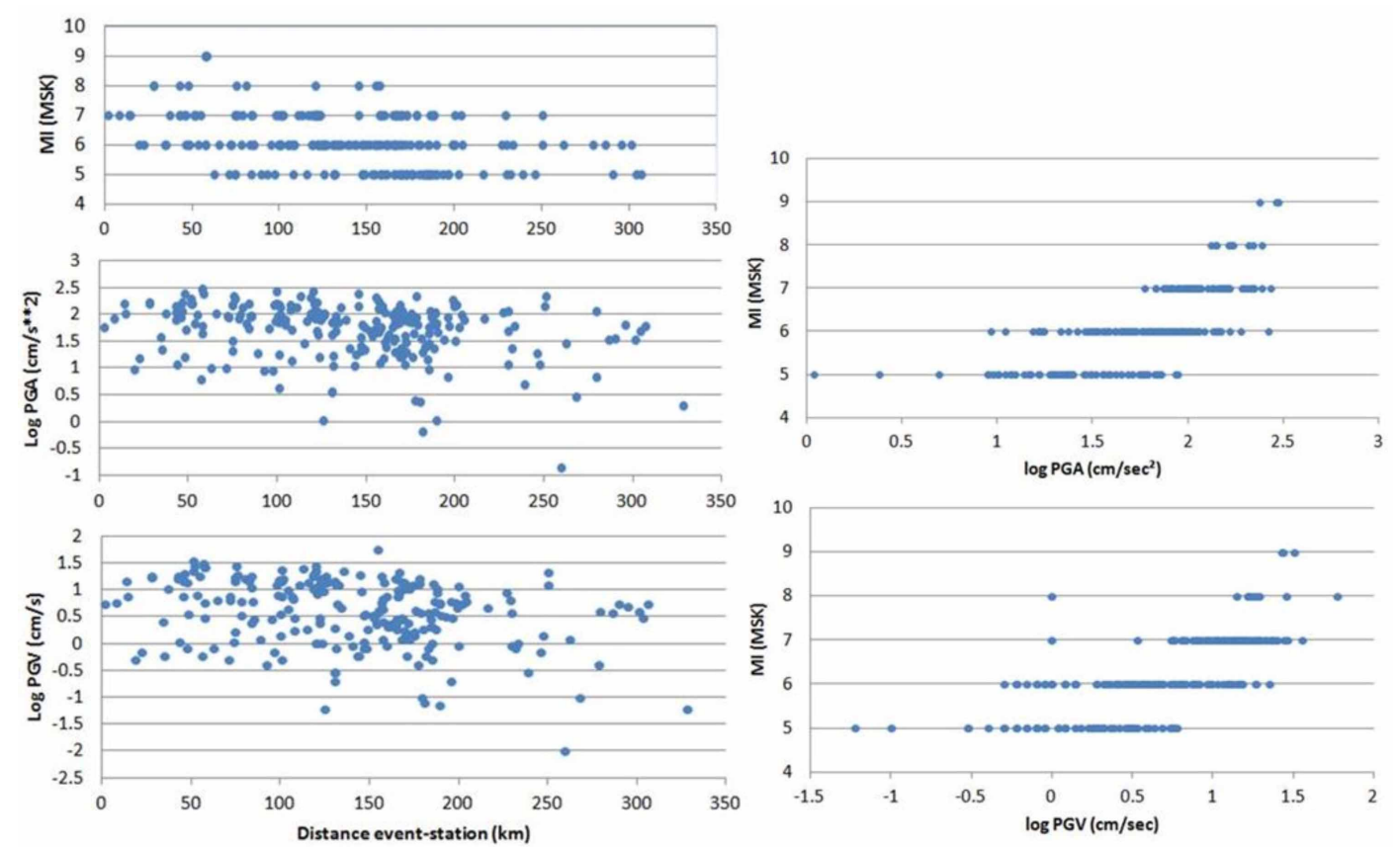

Figure 4. Distance coverage of the MI-PGM pairs used in this study: MI, log PGA, log PGV vs Distance. MI vs log PGM (right side). The distance is determined using the epicentral location of the earthquakes.

\subsection{Orthogonal Distance Regression}

It is known that the simple least-squares is the most frequently applied technique for fitting data to models and for estimating parameters of the models. But it is also known that this regression can never be inverted, that is, the regression of a parameter/variable against another cannot be inverted to derive the reverse regression of the same parameters. For this reason, the ODR is a more appropriate technique in problems where dependent and independent variables are both affected by uncertainty [Faenza and Michelini, 2010]. In this case, the use of the orthogonal regression technique allows also for the direct inversion between MI and PGM so that the computed coefficients can be used to obtain PGM as a function of MI.

First, we performed ODR of intensities versus accelerations and velocities for all the stations and some of them showed a large scatter. The relation between the intensity and ground motion parameters can be written in the form of a relatively simple equation, in terms of intensity and PGA or PGV, using all data: 


\section{Angela Petruta Constantin et al.}

$$
M I=\mathrm{a}+\mathrm{b} * \log P G M
$$

Next, the geometric mean was calculated using the recorded values for PGA and PGV for every intensity class (Table 6).

\begin{tabular}{cccccc}
$\begin{array}{c}\text { Intensity } \\
\text { (MSK) }\end{array}$ & No. of points & $\begin{array}{c}\text { PGAmax } \\
\left(\mathbf{c m} / \mathbf{s}^{2}\right)\end{array}$ & $\begin{array}{c}\text { The geometric } \\
\text { mean of logPGA }\end{array}$ & $\begin{array}{c}\text { PGVmax } \\
(\mathbf{c m} / \mathbf{s})\end{array}$ & $\begin{array}{c}\text { The geometric } \\
\text { mean of logPGV }\end{array}$ \\
\hline V & 57 & 87.6 & 1.27 & 6 & 0.17 \\
\hline VI & 86 & 264.4 & 1.72 & 22.3 & 0.60 \\
\hline VII & 62 & 270.6 & 2.07 & 58.5 & 1.11 \\
\hline VIII & 10 & 241.6 & 2.23 & 31.9 & 1.31 \\
\hline IX & 3 & 297.1 & 2.43 & & 1.45 \\
\hline
\end{tabular}

Table 6. Description of matched MI-PGM, including the number of pairs, and the MI and distance range covered.

Regression coefficients are obtained for the relations between macroseismic intensity and the geometric mean of the logarithm of the peak ground motion parameters. With the single-line regression, we have obtained for MI vs. PGA and PGV, the following relations:

$$
M I=0.169+3.51 * \log P G A
$$

(for the interval of $\mathrm{V} \leq \mathrm{MI} \leq \mathrm{IX}$ )

$$
M I=4.16+3.04 * \log P G V
$$

(for the interval of $\mathrm{V} \leq \mathrm{MI} \leq \mathrm{IX}$ )

In Table 7 we list the parameters derived for each equation, i.e. a, b regression coefficients and their errors; $\sigma^{2}{ }_{e}$, the squares of the errors variances in both variables, intensity and ground motion; $\sigma^{2}{ }_{r e s}$, the square of the residual errors variance and R-squared values. In estimating the model, it was assumed that the ratio between the variance of the errors in PGA and PGV and the variance of the errors in MI is equal to 1.5. As in literature it is used for good results, we also applied in our study this value of error variance ratio. The fitted model minimizes the sum of squared residuals, where the residuals measure the angular distance from the observed data values to the fitted line. In this case, the estimated variance of the residual errors is 0.34 for PGA, and 0.38 for PGV respectively. Regression coefficients, standard errors and regression residual parameters were calculated with Statgraphics software [www.statgraphics.com].

\begin{tabular}{ccccccc} 
PGM & $\mathbf{a}$ & $\mathbf{b}$ & $\mathbf{M I}$ & $\mathbf{\sigma _ { e } ^ { 2 }}$ & $\boldsymbol{\sigma}_{\text {res }}^{2}$ & $\mathbf{R}^{2}$ \\
\hline $\mathrm{PGA}\left(\mathrm{cm} / \mathrm{s}^{2}\right)$ & $0.169 \pm 0.87$ & $3.51 \pm 0.43$ & 0.11 & 0.09 & 0.34 & 0.977 \\
\hline $\mathrm{PGV}(\mathrm{cm} / \mathrm{s})$ & $4.16 \pm 0.44$ & $3.04 \pm 0.42$ & 0.14 & 0.11 & 0.38 & 0.972 \\
\hline
\end{tabular}

Table 7. The parameters of the proposed regressions.

The results of intensities correlation with PGA and PGV for the six Vrancea subcrustal earthquakes are plotted in Figures 5 and 6 . The dashed lines from these plots were added to the regression line to show how the data spread is captured and were determined based on approximately $95 \%$ of the data points being in this range (that extends from $+/-2 \sigma$ ) of the regression from the fitted line. By analyzing these graphics one can observe a clear increased 
tendency of the PGM with the increase of the macroseismic intensity. However, there is also an obvious spreading of the PGA and PGV for each degree of intensity, thus one recorded PGA value corresponds to two, three or even four degrees of intensity. Moreover, these acceleration values spreading for certain degrees of intensity have been previously observed in other MI-PGA correlation studies [Trifunac and Brady, 1975; Murphy and O’Brien, 1977; Wald et al., 1999b; Locati et al., 2017]. But the large spread of the PGM values for each macroseismic intensity level can be explained by the nature itself of these parameters that characterize the seismic ground motion. On the other hand, the macroseismic intensity is evaluated based on the description of the earthquake effects observed by the population, sometimes subjective, on the environment and buildings. Another aspect that contributes to this spread is that the maximum value of the ground motion parameters is recorded in a single point, unlike the macroseismic intensity which refers to the moderate or maximum effects produced by the earthquake and observed on a certain area. Although 218 pairs of MI-PGM represent a considerably set for major Vrancea earthquakes that occurred in that period, the number of PGM used for correlation with MI is still not enough to cover lower intensity levels, and also, above VIII degree.

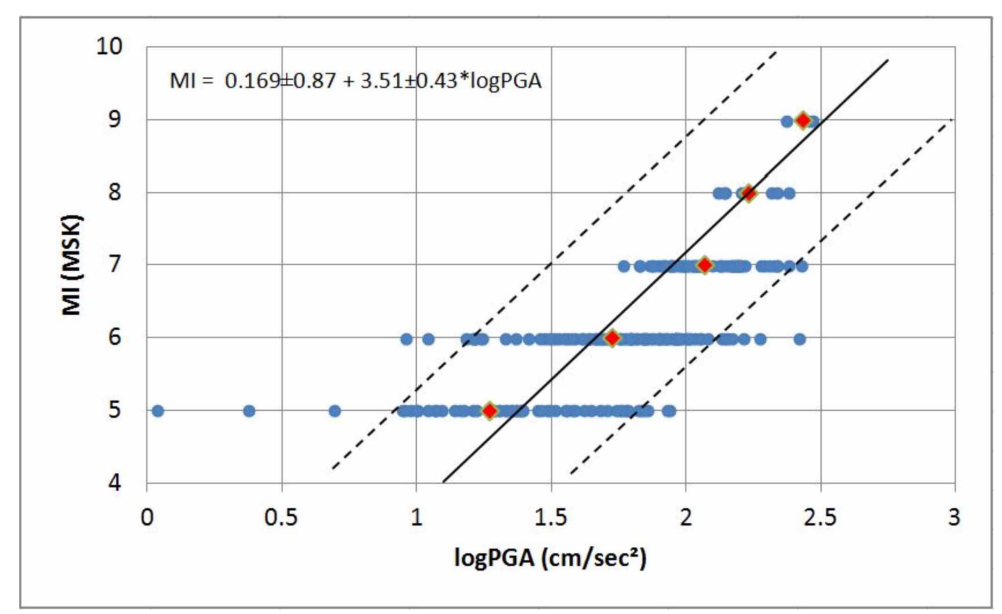

Figure 5. Fully-reversible intensity-PGA relation for six Vrancea subcrustal earthquakes. Blue dots denote data and black solid line the regression for the geometric mean (red diamonds) for each intensity degree. The dashed lines show the $+/-2 \sigma$.

Using relations 2 and 3 we have determined the predicted PGA and PGV intervals for each MI degree (see Table 8).

Intensity (MSK)

PGA range $\left(\mathrm{cm} / \mathrm{s}^{2}\right)($ eq. 2$)$

PGV range $(\mathrm{cm} / \mathrm{s})($ eq. 3)

\begin{tabular}{ccc} 
V & $17.17 \div 33.08$ & $1.3 \div 2.75$ \\
\hline VI & $33.09 \div 63.79$ & $2.76 \div 5.87$ \\
\hline VII & $63.8 \div 122.99$ & $5.88 \div 12.49$ \\
\hline VIII & $123 \div 237.13$ & $12.5 \div 26.6$ \\
\hline IX & $237.14 \div 457.1$ & $26.69 \div 56.6$ \\
\hline
\end{tabular}

Table 8. Proposed ranges of PGA and PGV for each MI in Vrancea subcrustal region using ODR.

Since the macroseismic intensities used in this study are only constituted by the integer numbers, PGM interval limits were obtained after a rounding convention such as values between 4.50 and 5.49 round to intensity V. 


\section{Angela Petruta Constantin et al.}

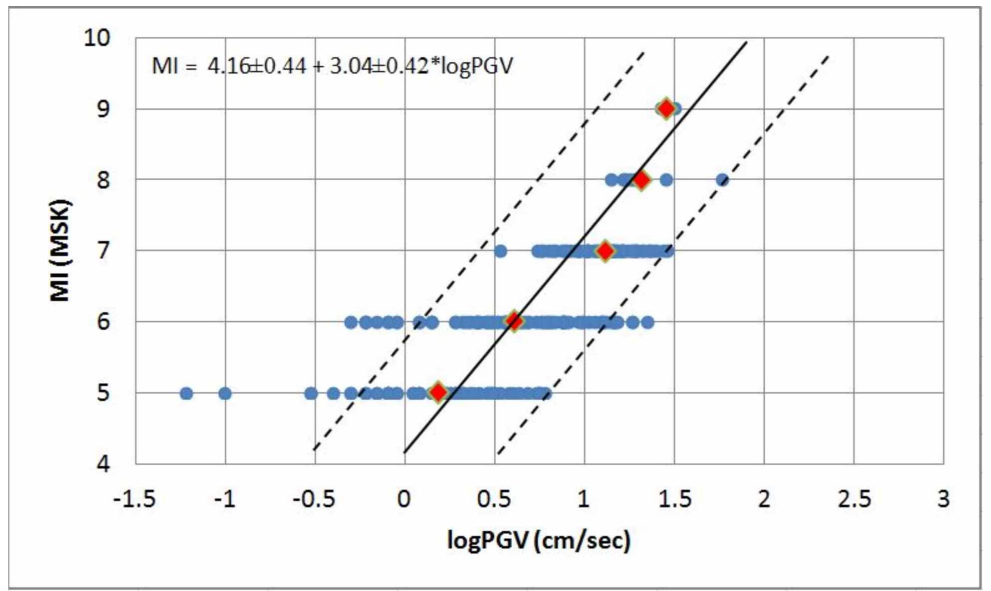

Figure 6. Fully-reversible intensity-PGV relation for six Vrancea subcrustal earthquakes. Blue dots denote data and black solid line the regression for the geometric mean (red diamonds) for each intensity degree. The dashed lines show the $+/-2 \sigma$.

The regressions proposed in the present study are compared to other alternative regressions developed for the same seismic zone by Sørensen et al. [2008] based on a dataset which consists of 46 MI- PGA pairs and 30 MI-PGV pairs related to only 4 earthquakes, Enescu [1997] and Bonjer et al. [2001] for the same events with $\mathrm{M}_{\mathrm{W}}>6$ (1977, 1986 and two from 1990). The resulting comparison among the proposed regressions and the previous studies are presented in Figure 7. The MI-PGA regression proposed by Sørensen et al. [2008] returns smaller intensity values with approximately one degree for MI $\leq$ VII MSK. While comparing the results of the present study with the ones obtained by Enescu [1997] and Bonjer et al. [2001], it is noticed that their equations provide lower intensity values as well.
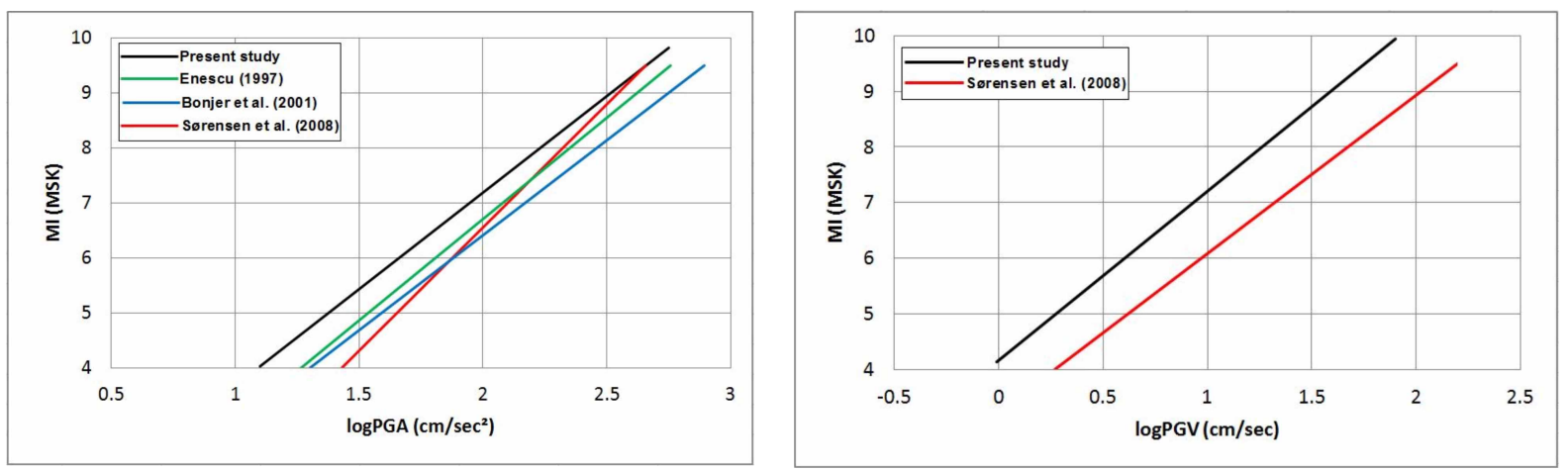

Figure 7. Comparison of the MI-PGA (left) and MI-PGV (right) relationships obtained in this paper with previous relations developed for Vrancea subcrustal earthquakes.

When compared MI-PGV relation from this study with Sørensen et al. [2008], it is observed that the equation proposed by Sørensen et al. [2008] gives lower intensity values by approximately one intensity degree. The comparison among these four studies has to face the differences between datasets and number of earthquakes, the criteria to select the recorded ground motion and to pair them with the intensity values and the regression types used to fit the data. All previous studies mentioned before have used a ordinary least-squares linear technique.

The next step in our analysis was to verify if there is a correlation of the MI residuals $\left(\mathrm{MI}_{\mathrm{observed}}-\mathrm{MI}_{\text {predicted }}\right)$ with magnitude and epicentral distance. The results for the data set of all six analyzed earthquakes are shown in Figure 8. 

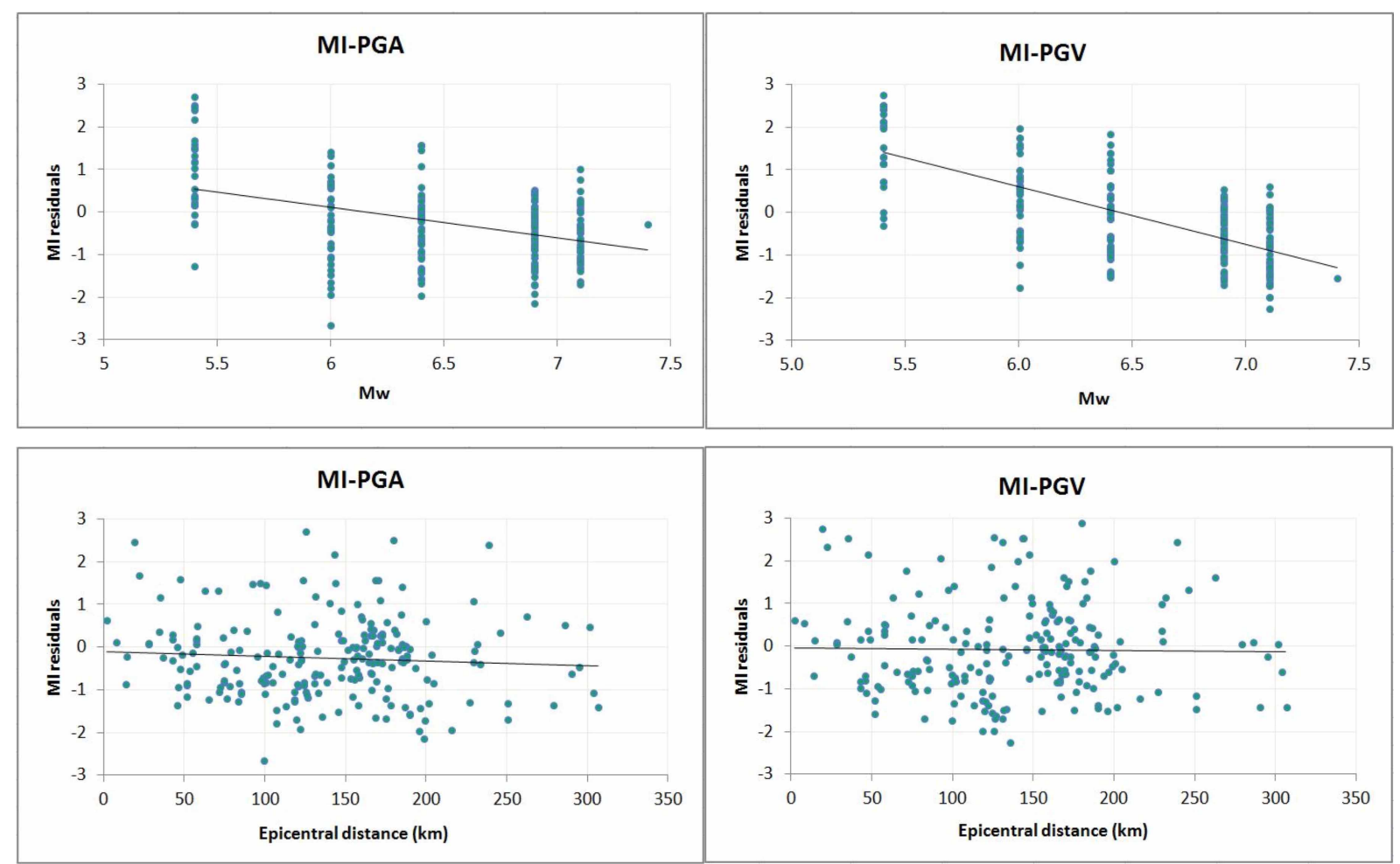

Figure 8. Analysis of the dependencies of residual intensities $\left(\mathrm{MI}_{\mathrm{observed}}-\mathrm{MI}_{\text {predicted }}\right)$ from the ground motion parameters using equations 2 and 3 as function of magnitude (top) and epicentral distance (bottom).

A notable dependency with magnitude is observed, with negative slope, in both plots for the residuals for MI predicted from the ground motion parameters. The plot of MI residuals against epicentral distance for both PGA and PGV show that no significant trend occurs for our data set. But many previous studies have published the regression without magnitude, distance and/or local conditions dependency [i.e., Gòmez Capera et al., 2007; Faenza and Michelini, 2010; Zanini et al., 2019]. In a future work, we do intend to produce a new regression relation that include the effects of magnitude, distance and/or geological conditions on a much consistent data set (with more recent earthquakes) with an extended range of magnitude. The principal purpose of this study was to obtain a reliable relation between recorded ground motion parameters and MI for a rapid estimation of intensity (besides online questionnaires) to offer a quick answer to population, governmental institutions and insurance companies in case of moderate and major Vrancea earthquakes.

These relations are very useful for a rapid estimate of MI from the recorded PGM at Romanian seismic stations, before obtaining MI reported from the field, but we need to have in mind that instrumental parameters are not directly associated with real damage. The degree to which various MI intervals have overlapping PGA and PGV values will show us how good MI is reflected by these ground motion parameters.

\section{Conclusions}

The main purpose of this paper was the analysis of the macroseismic and instrumental data, collected and recorded during the last 6 significant/strong Vrancea earthquakes $(5.4<\mathrm{Mw}<7.4)$ occurred between 1977-2009, in order to develop scaling relations between observed intensity and ground motion parameters. The main remarks may be summarized as follows:

- In addition to other studies about the MI-PGM correlation, in this study compilation of the data set resulted in 218 pairs from 6 earthquakes are considered, including the events from October 2004 and April 2009. Since the macroseismic intensity value is not directly associated with PGA and PGV values, which are obtained from one point, relationships were obtained by regression between the MI and geometric mean of PGA and 


\section{Angela Petruta Constantin et al.}

PGV for each intensity level. Correlations were developed for the intensity range of $\mathrm{V} \leq \mathrm{MI}$ (MSK) $\leq \mathrm{IX}$. In this study we opted for an orthogonal regression which allows for uncertainty on both variables (i.e., MI and PGM), and produces reversible relationships (equations 2 and 3). We applied the technique on the geometric means of the PGA and PGV for ODR regression approached in this study. After that, we have tested the obtained relations to find the predicted PGA and PGV intervals for each MI value. The predicted macroseismic intensity values using the PGM parameters are with $+/$ - one half a unit most of the time and $+/$ - one unit, in general. All the relations obtained in this study were computed independently of the epicentral distances and Mw of the analyzed earthquakes. The next step in such direction will be the development of new relations between MI and PGM which will take into consideration the epicentral/hypocentral distance and the magnitude of the seismic events.

- The regression analysis, adopted in various studies, showed that the potential damage associated with an earthquake (high intensities) correlate much better with PGV values than with PGA values [Wald et al., 1999b; Atkinson and Kaka, 2006; Faccioli and Cauzzi, 2006; Gomez-Capera et al., 2020]. One of the reasons might be the sharp PGA spikes which are usually characterized by single peak rich in high frequencies. These spikes are generally non-damaging but for sure will determine an over-estimation of the earthquake intensity. After the correlation between MI and PGM, we deduced the empirical relationships that might confer a more quantitatively character to the macroseismic intensity using records from the strong-motion network installed in Romania.

- The proposed equations between these parameters were determined to be used for the rapid assessment of ground shaking severity (Shake Map application) and potential damages in the areas affected by the Vrancea earthquakes. Also, these types of correlations give the macroseismic intensity parameter a more suitable engineering character, in order to be considered in risk studies, as well as in design practice.

The use of instrumental data should be considered as an approximate way of completing the information provided by the macroseismic investigations and vice versa, keeping in view the fact that the limitation of the seismic equipment installed on a territory will exist in the future too, comparing with the number of human observers that will be out there on the ground and notice the earthquakes effects. Finally, it is important to calibrate the relations used for intensity estimations in such a manner as to provide the best possible correlation with the existing intensity database, obtained on macroseismic criteria. The bottom line, we need more ground motion records and macroseismic intensity values from strong earthquakes to refine the results.

Acknowledgments. This paper was partially carried out within Nucleu Program, supported by ANCSI, MULTIRISC, project no. 190801 02/2019 and PED Program supported by UEFISCDI, Phenomenal project no. 480PED/2020.

\section{References}

Airinei, S. (1977). Geneza pamantului. Evolutia si structura lui interna., in Ed. Stiintifica si Enciclopedica, Bucuresti. Apostol, B.F., S.F. Balan and, A. Tiganescu (2020). Investigations of the seismic site response for safer urban environment, Romanian Journal of Physics, 65, 9-10, 814.

Ardeleanu, L., B. Grecu and, V. Raileanu (2012). Peak ground acceleration, velocity and displacement from moderate magnitude undercrustal earthquakes of Vrancea region, Romanian Reports in Physics, 64, 2, 555-570.

Atanasiu, I. (1961). Cutremurele de pamant din Romania, in Ed. Acad., Bucuresti, 194.

Atkinson, G.M. and S.L. Kaka (2006). Relationships between Felt Intensity and Instrumental Ground Motion in Central United States and California, Bull. Seism. Soc. Am., 91, 2, 497-510.

Bilal, M. (2013). Relationships between felt intensity and recorded ground motion parameters for Turkey, $\mathrm{PhD}$ Thesis, School of natural and applied sciences of Middle East Technical University.

Bonjer, K.P., V. Sokolov, W. Wirth, M. Rizescu, L. Driad and, M. Treml (2001). The seismogenic potential of the Vrancea subduction zone-quantification of source and site effects of great events, in Collaborative Research Center (CRC) 461 "Strong Earthquakes: a Challenge for Geosciences and Civil Engineering”, Report of 1999-2001, University of Karlsruhe, 259-293 (in German). 


\section{Correlation of intensity with ground motion parameters}

Borcia, I.S. (2006). Procesarea înregistrărilor mişcărilor seismice puternice specifice teritoriului României, $\mathrm{PhD}$ Thesis, UTCB, Bucureşti.

Campbell, K.W. (1981). Near source attenuation of peak horizontal acceleration, Bull. Seism. Soc. Am.,71, 20392070.

Campbell, K.W. (1983). The effects of site characteristics a near-source recordings of strong ground motion, in Proc. Of Conf. XXII- A Workshop on Site Specific Effects of Soil and Rock on Ground Motion and Their Implications for Earthquakes Resistant Design, Santa Fe, New Mexico, U.S. Geol, Survey Open File Report, 280-309.

Caprio, M., B. Tarigan, C.B. Worden, S. Wiemer and, D.J. Wald (2015). Ground Motion to Intensity Conversion Equations (GMICEs): A Global Relationship and Evaluation of Regional Dependency, Bull. Seism. Soc. Am., 105, 1476-1490.

Chernov, Y. and V. Sokolov (1988). Earthquake felt intensity estimation using the strong ground motion spectra, Eng. Seismol. Probl., 29, 62-73.

Chiaruttini, C. and L. Siro (1981). The correlation of peak ground horizontal acceleration with magnitude, distance, and seismic intensity for Friuli and Ancona, Italy, and the Alpide Belt, Bull. Seism. Soc. Am.,71 (6), 1993-2009.

Constantin, A.P., A. Pantea and R. Stoica, (2011). Vrancea (Romania) Subcrustal Earthquakes: Historical Sources and Macroseismic Intensity Assessment, Romanian Journal of Physics, 56, 5-6, 813-826.

Constantin, A.P. and A. Pantea (2013). Macroseismic field of the October 27, 2004, Vrancea (Romania) moderate subcrustal earthquake, Journal o Seismology, 17, 4, 1149-1156.

Constantin, A.P., I.A. Moldovan, A. Craiu, M.Radulian and C. Ionescu (2016). Macroseismic intensity investigation of the November 2014, M=5.7, Vrancea (Romania) crustal earthquake, Ann. Geophys., 59, 5, 50542.

Constantin, A.P., R. Partheniu, I.A. Moldovan and A. Pantea (2018). The intensity assessment of April 25, 2009, Vrancea subcrustal earthquake from macroseismic data, Rom. Rep. Phys., 70, 703.

Constantin, A.P., E.F. Manea, I.A. Moldovan, and R. Partheniu (2020). Testing the macroseismic intensity attenuation relationships for Vrancea (Romania) subcrustal earthquakes in relation with dams situated in extra-Carpathian area, SWS, J. Earth Planet. Sci., 2, 2, 17-34.

Enescu, D. (1997). Ground movement acceleration-macroseismic intensity relations for Vrancea earthquakes. Considerations of the macroseismic maps of some of these earthquakes, St. Cerc. Geofizica, 35, 15-27.

Faccioli, E. (1981). The use of RMS acceleration as a measure of soil amplification on strong earthquakes, in State of the Art in Earthquakes. Engineers, Ankara, Turkey.

Faccioli, E. and C. Cauzzi (2006). Macroseismic intensities for seismic scenarios, estimated from instrumentally based correlations, in First European Conference on Earthquake Engineering and Seismology, Geneva, Switzerland, 3-8 September 2006.

Faenza, L., A. Michelini (2010). Regression analysis of MCS intensity and ground motion parameters in Italy and its application in ShakeMap, Geophys. J. Int.,180, 1138-1152.

Gomez Capera, A.A., D. Albarello and P. Gasperini (2007). Aggiornamento delle relazioni fra l'intensità macrosismica e PGA. Technical report, Progetto S1, Task 2, deliverable D11, Istituto Nazionale di Geofisica e Vulcanologia, Sezione di Milano-Pavia, http://esse1 .mi.ingv.it/d11.html.

Gomez-Capera, A.A., M. D’Amico, G. Lanzano, M. Locati and M. Santulin (2020). Relationships between ground motion parameters and macroseismic intensity for Italy, Bull. Earthq. Eng., 18, 5143-5164.

Grecu, V., V. Burlacu, A. Pantea and M. Radulian (1981). Metode si programe de calcul pentru prelucrarea accelerogramelor inregistrate, Contract CFPS /CSEN. Tema 30.81.8/1981.

Hepites, S. (1902). Cutremurele de pământ din România în anul 1902 şi în deceniul 1892-1902: [statistică pe 10 ani (1893-1902)].

Linkimer, L. (2008). Relationship between peak ground acceleration and modified Mercalli intensity in Costa Rica, Revista Geológica de América Central, 38, 81-94, ISSN: 0256-7024.

Locati, M., C. Gómez, A. Augusto, R. Puglia and M. Santulin (2017). Rosetta, a tool for linking accelerometric recordings and macroseismic observations: description and applications, Bull. Earthq. Eng., 15, 19-29.

Kaka, S. and G. Atkinson (2004). Relationships between instrumental ground-motion parameters and modified Mercalli intensity in eastern North America, Bull. Seism. Soc. Am., 94, 1728-1736.

Kramer, S.L. (1996). Geotechnical earthquake engineering, in Prentice-Hall International Series, 659, ISBN 9780133749434.

Marmureanu, G., N. Androne, M. Radulian, E. Popescu, C.O. Cioflan, A.O. Plăcintă, I.A. Moldovan and V. Serban 


\section{Angela Petruta Constantin et al.}

(2006). Attenuation of the peak ground motion for the special case of Vrancea intermediate-depth earthquakes and seismic hazard assessment at NPP Cernavoda, Acta Geodaetica et Geophysica Hungarica, 41, 433-440.

Marmureanu, G., I.S. Borcia, A. Marmureanu, C.O. Cioflan, D. Toma-Danila, I. Ilies, G.M. Craiu and I. Stoian (2020). Larger peak ground accelerations in extra-Carpathian area than in epicenter, Rom. J. Phys., 65 (5-6), 811.

Mandrescu, N. (1995). Cutremurele subcrustale din anii 1986 (30 August) si 1990 (30 si 31 Mai): Semnificatii geologice si seismologice, St. Cerc. Geofiz, 33, 31-49.

Medvedev, S.V., W. Sponheuer and V. Karnik (1967). Seismic intensity scale version MSK 1964, in Publ. Inst. Geodynamik, 48, Jena.

Moldovan, I.A., B.D. Enescu and C. Ionescu (2000). Predicting Peak Ground Horizontal Acceleration for Vrancea Large Earthquakes Using Attenuation Relations for Moderate Shocks, Rom. J. Phys., 45, 9-10, 785-800.

Murphy, J.R. and L.J. O’Brien (1977). The correlation of peak ground acceleration amplitude with seismic intensity and other physical parameters, Bull. Seism. Soc. Am., 67, 877-915.

Nemati, M. (2015). Relationship between Modified Mercalli Intensity and Engineering Ground-Motion of the Earthquakes in Persia, J. Earthq. Eng., 00, 1-14.

Ogweno, L.P. and C.H. Cramer (2017). Improved CENA Regression Relationships between Modified Mercalli Intensities and Ground-Motion Parameters, Bull. Seism. Soc. Am.,107, 180-197.

Oncescu, M.C., V.I. Marza, M. Rizescu and M. Popa (2000). The Romanian earthquake catalogue between 984-1997, In: F. Wenzel, D. Lungu (eds.) and O. Novak (coed.), Vrancea Earthquakes: Tectonics, Hazard and Risk Mitigation, Kluwer Academic Publishers, Dordrecht, Netherlands, 43-47.

Pantea, A. (1992). Relatii empirice intre intensitatea MM si acceleratie, Tema 30.92.1/1992, Faza decembrie, Cap. A.

Pantea, A. and E. Crisan (1993). Atenuarea acceleratiei maxime a terenului (PGA) cu distanta pe baza inregistrarilor retelei digitale (LENNARTZ). Partea I. Obtinerea unor accelerograme, Tema 30.92.1. Cap.16.

Pantea, A. (1999). Studii teoretice si aplicative privind caracteristicile dinamice ale undelor produse de explozii, PhD Thesis, Universitatea Bucuresti, 251.

Pantea, A. and A.P. Constantin (2011). Reevaluated macroseismic map of Vrancea (Romania) earthquake occurred on November 10, 1940. Rom J. Phys, 56, 3-4, 578-589.

Pantea, A. and A.P. Constantin (2013). Re-evaluation of the macroseismic effects produced by the March 4, 1977, strong Vrancea earthquake in Romanian territory, Ann Geophys, 56, 1, R0104.

Popescu, E., C.O. Cioflan, M. Radulian, A.O. Placinta and I.A. Moldovan (2007). Attenuation relations for the seismic ground motion induced by Vrancea intermediate-depth earthquakes, in Proc. of the International Symposium on Strong Vrancea Earthquakes and Risk Mitigation, Oct. 4-6, 2007, Bucharest, Romania.

Ren, Y., K. Ji, R. Wen and X. Huang (2013). Field survey around strong motion stations and its implications on the seismic intensity in the Lushan earthquake on April 20, 2013, Earthq. Sci., 26, 3-4, 241-250.

Radu, C., A. Utale and V. Winter (1987). Cutremurul Vrancean din 30 August 1986: Distributia Intensitatilor Seismice, in Raport CFPS/CSEN, Tema 30.86.3/1987, II, A3ICEFIZBucuresti, 25 mai 1987.

Radu, C., D. Radulescu and H. Sandi (1990). Some data and considerations on recent strong earthquakes of Romania, Cahier Technique, no. 3, AFPS.

Radu, C. and A. Utale (1990). Cutremurul Vrancean din 30 Mai 1990: Distributia Intensitatilor Seismice, in Raport CFPS/IFA, Tema 30.86.3/1990, IV, A2, 10, Bucuresti, 25 Decembrie 1990.

Radu, C. (1991). The Vrancea Romania 30 May 1990 major earthquake: seismological and engineering aspects, The 20th IUGG General Assembly, IASPEI, S7, Vienna.

Radu, C. and A. Utale (1991). Cutremurul Vrancean din 31 Mai 1990: Distributia Intensitatilor Seismice, in Raport CFPS/IFA, Tema 30.91.3/1991, I, 4, 10, CFP, Bucuresti, 25 Iunie 1991.

Romplus catalogue (2019). Updated to 2019 by the Department of Data Acquisition of the National Institute for Earth Physics (NIEP), Bucharest.

Sandi, H. (1986). An engineer's approach to the scaling of seismic intensity, Proc. 8-th ECEE, Lisbon.

Sandi, H. (1990). An approach to the development of an up-to-date intensity scale, Proc. 9-th ECEE, Moscow.

Sørensen, M.B., D. Stromeyer and G. Grünthal (2008). Estimation of macroseismic intensity - new attenuation and intensity versus ground motion relations for different parts of Europe, inProceedings of the 14th World Conference on Earthquake Engineering, October 12-17, 2008, Beijing, China.

Sweny, A. (2012). Relationships between Earthquake Ground Motions and Modified Mercalli Intensity, PhD thesis, The University of Western Ontario. 
STAS 3684-71 (1971). Macroseismic intensity scale. Romanian Institute of Standardization, IRS, Bucharest.

Trifunac, M.D. and A.G. Brady (1975a). On the correlation of seismic intensity with peaks of recorded ground motion, Bull. Seism. Soc. Am., 65, 139-162.

Wald, D.J., V. Quitoriano, T.H. Heaton, H. Kanamori, C.W. Scrivner and C.B. Worden (1999a). TriNet "ShakeMaps”: Rapid Generation of Peak Ground Motion and Intensity Maps for Earthquakes in Southern California, Earthquake Spectra, 15, 3, doi:10.1193/1.1586057.

Wald, D.J., V. Quitoriano, T.H. Heaton and H. Kanamori (1999b). Relationships between peak ground acceleration, peak ground velocity, and modified Mercalli intensity in California, Earthquake Spectra, 15, 3, 557-564.

Wald, D. J., V. Quitoriano, L.A. Dengler and J.W. Dewey (1999c). Utilization of the Internet for Rapid Community Intensity Maps, Seismol. Res. Lett., 70, 6, 680-697.

Wald, D.J., P.S. Earle, K. Lin, V. Quitoriano and B. Worden (2006). Challenges in rapid ground motion estimation for the prompt assessment of global urban earthquakes, Bull. Earthq. Res. Inst., Univ. Tokyo, 81, 275-283.

Zanini, M.A., L. Hofer, and F. Faleschini (2019). Reversible ground motion-to-intensity conversion equations based on the EMS-98 scale, Engineering Structures, 180, 310-320. 